\title{
Editorial
}

\section{Infection Control and Hospital Epidemiology Outside the United States}

\author{
Andreas F. Widmer, MD, MS; Hugo Sax, MD; Didier Pittet, MD, MS
}

Florence Nightingale (1820-1907) is considered the first infection control (IC) nurse. ${ }^{1}$ Her work with the epidemiologist William Farr in England was one of the first examples in history demonstrating the effectiveness of close collaboration between IC nurses and hospital epidemiologists. Another very important European contribution to the science of IC was that of Ignaz F. Semmelweis of Vienna, Austria, who demonstrated in 1847 the impact of hand antisepsis on cross-infection and maternal death from puerperal fever. ${ }^{1}$

Readers may have noticed that many of the articles in the January issue are from countries outside the United States. This was not the result of any effort of the editors to cluster international contributions, but rather a simple chance event that reflects the increasing number of quality submissions from international authors.

In the United States, landmark studies by Haley et al ${ }^{2}$ in the 1970 s triggered the rapid evolution of IC in the clinical setting. Ongoing surveillance of nosocomial infections (NIs) then was initiated and was stimulated further when IC and surveillance activities were mandated by the Joint Commission for the Accreditation of Healthcare Organizations. The implementation of diagnosis-related groups added a financial incentive to reduce the incidence of NIs.

In contrast, routine surveillance and large-scale trials to limit the incidence of NIs were not performed in Europe in the 1970s. IC efforts in Europe and other countries rely primarily on the microbiology laboratory and hospital hygiene. IC often is not mandatory. Most hospitals outside the United States still are reimbursed based on a fee for service or on days of hospitalization. Therefore, these countries lack financial incentives to reduce NI rates. However, morbidity and mortality associated with NIs are wellrecognized problems in non-US countries. In Europe, the rapidly evolving healthcare system awaits changes such as those observed in the late 1980s in the United States that will add a financial incentive to combat NIs.

Human and financial resources allocated to IC have increased markedly in Western Europe. In Germany, a national reference center for NIs was created in the early 1990s (Nationales Referenzzentrum für Krankenhaushygiene in Berlin and Freiburg). The Netherlands relies on a sophisticated network for IC linking all teaching hospitals. In Belgium, the Institut Scientifique de la Santé Publique Louis Pasteur provides scientific support for hospital epidemiology activities. Moreover, the Association Belge pour l'Hygiène Hospitalière (IC nurses) and the Groupement pour le Dépistage, l'Etude et la Prévention des Infections Hospitalières (IC doctors) are working together to conduct surveillance and promote IC nationwide.

A first national study of the prevalence of NIs in the United Kingdom was conducted in 1980. An audit coordinated by the Public Health Laboratory Service in Colindale (London) and funded by the Department of Health was conducted from 1993 to 1994 with the objectives of developing a national database and IC practice guidelines that could be used by National Health Service, private, and voluntary hospitals. Local surveillance and control of NIs is the current practice in the United Kingdom. A recent report by a combined working party could be given as an example of a trend toward a global and nationwide approach to IC. ${ }^{3}$ Currently, the Nosocomial Infection National Surveillance Scheme (NINSS) is being established by the Public Health Laboratory Service to develop surveillance of NI in the health service. ${ }^{4}$

From the University Hospital of Basel (Dr. Widmer), Basel; the University Hospitals of Geneva (Drs. Sax and Pittet), Geneva, Switzerland.

The authors wish to express their gratitude to colleagues and friends in hospital epidemiology and infection control for providing them with some of the information contained in this work, and in particular to G. Dziekan, P. Gastmeier, and the members of the INSPEAR project. They also thank S. Harbarth and $H$. Richet for careful reading of the manuscript.

Address reprint requests to Didier Pittet, MD, MS, Infection Control Program, University of Geneva Hospitals, Rue Micheli-du-Crest 24, 1211 Geneva 14, Switzerland.

98-ED-172. Widmer AF, Sax H, Pittet, D. Infection control and hospital epidemiology outside the United States. Infect Control Hosp Epidemiol 1999;20:17-21. 


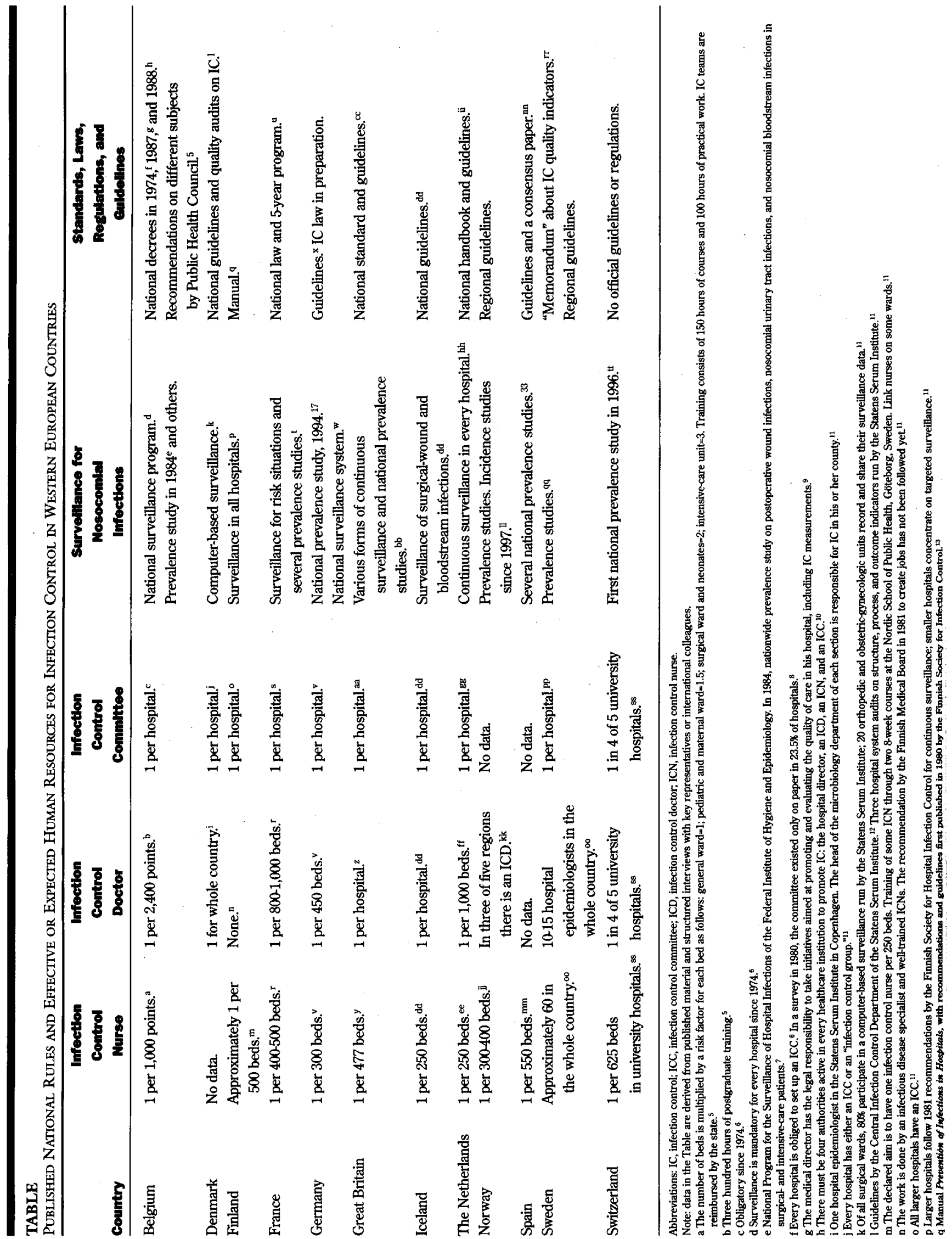


In 1992, the Comite Technique National de l'Infection Nosocomiale divided France into five large geographical areas for the coordination of IC activities. A national prevalence study of NIs has been conducted. Surveillance networks for surgical-site infections, intensivecare-unit-acquired infections, or control of multiresistant organisms were developed, and national IC guidelines have been issued. These examples illustrate trends in Western Europe; many other examples could have been cited.

As of the end of the 1990s, most countries in Western Europe have guidelines for the prevention of NIs and a recommendation for IC nurse and physician ratios based on hospital size (Table). Strategies and resources to prevent NIs differ between countries. Many hospitals rely on written guidelines for IC; some are available on the Internet. Only a few hospitals perform ongoing surveillance for NIs similar to that of US hospitals that are linked with the National Nosocomial Infection Surveillance (NNIS) System of the Centers for Disease Control and Prevention, Atlanta, Georgia. Prevalence studies are preferred, primarily due to limited resources. Repetitive prevalence surveys commonly are used to assess the importance of NIs and the impact of IC. ${ }^{38,39}$ Large, multicenter, multinational prevalence studies have been conducted, in particular in intensive-care units. ${ }^{40,41}$ The European Prevalence of Infection in Intensive Care study ${ }^{40}$ showed a linear relationship between the prevalence of NIs in critical care and mortality. It became clear that the prevalence of NIs in Western Europe was very similar to that observed in the United States. However, Europe lacks a centralized entity such as the NNIS System, where data are collected, analyzed, and reported in a standardized fashion.

National and international meetings provide further evidence for the rapidly evolving activities and importance of IC outside the United States. Examples in Europe include, in particular, internationally recognized meetings of the Hospital Infection Society in the United Kingdom and the International Conference on the Prevention of Infection in France. The European Society for Clinical Microbiology and Infectious Diseases is heading several study groups and collaborative surveys of NIs and IC. Finally, training programs for IC practitioners are available in several countries, and participation is mandatory in some.

Infection control has evolved rapidly outside the United States and Europe over the last decades. In Canada, the Canadian Nosocomial Infection Surveillance Program provides assistance and funding to some 20 hospitals to conduct collaborative surveillance studies on NIs around the country; a series of IC guidelines have been developed by the Laboratoire Canadien de Lutte Contre les Maladies (http://hwcweb.hwc.ca/hpb/lcdc/hp_eng.htlm). As recently stated, ${ }^{42}$ substantial progress has been made in recent years to improve IC in hospitals in countries with limited resources, including national initiatives in Asia and Latin America. Reductions in NI rates have been observed following the implementation of surveillance and control programs in some Latin America institutions. Efforts to develop uniform and global IC strategies still are needed. 


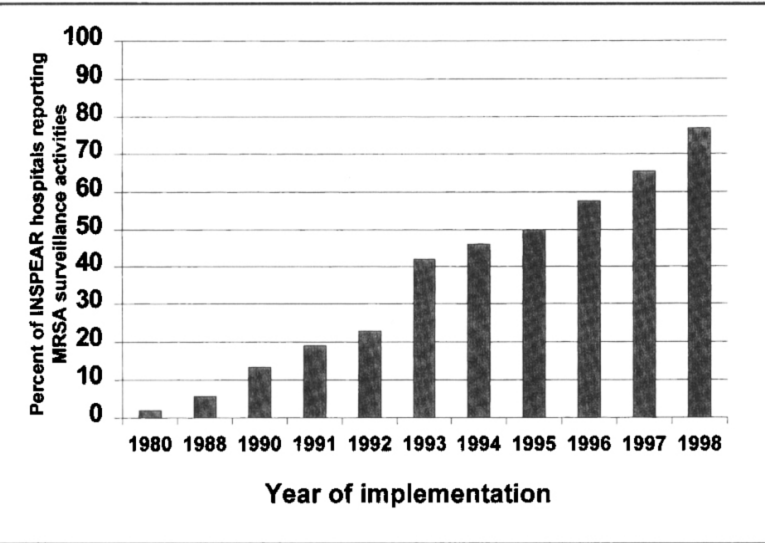

FIGURE 1. Trends in methicillin-resistant Staphylococus aureus (MRSA) surveillance activities-International Networks for the Study and Prevention of Emerging Antimicrobial Resistance (INSPEAR) project. In 1998, a questionnaire survey of MRSA surveillance and control activities was conducted among INSPEAR hospitals. The data presented are preliminary (as of August 1998) and summarize results obtained from 52 hospitals (teaching hospitals, 73\%; public hospitals, $85 \%$ ) in Argentina, Austria, Belgium, Brazil, Bulgaria, China, Croatia, Czech Republic, France, Germany, Greece, Italy, Poland, Romania, Spain, Switzerland, The Netherlands, Tunisia, the United Kingdom, and the United States). Types of MRSA surveillance and control activities varied widely among INSPEAR hospitals. For further information regarding the INSPEAR project, contact H. Richet, MD, at hmr3@cdc.gov.

International collaboration outside the United States frequently is hampered by different legal regulations, term and case definitions, microbiological methods (many European countries define their own break points for susceptibility testing) and, last but not least, different languages. In Europe, the European Union provides a common field for transnational collaboration and uniform regulation. Politically, France, Germany, and the United Kingdom have new center-left governments that might facilitate international collaboration in infectious diseases and $\mathrm{IC}$.

The data we report are derived mostly from published material. However, even excellent work is not always published or is published in journals difficult to obtain or to read in the native language. Experiences in the study of antimicrobial resistance, antibiotic use, and IC in several parts of the world-and in Eastern Europe in particular-are reported infrequently in the English peerreviewed literature. Furthermore, large networks are being created within Europe or including European hospitals: eg, European Community Nosocomial Infection Survey, 43 EURO.NIS; Hospitals in Europe Link for Infection Control Through Surveillance, HELICS; and European Antimicrobial Resistance Surveillance System, EARSS. There is a large body of evidence for the growing importance of IC activities worldwide. Secular trends in methicillin-resistant Staphylococcus aureus surveillance activities in several continents nicely illustrate these trends (Figure 1).

Long before the United States became one of the leading countries in NI control and prevention, several European journals already covered issues associated with IC. Examples are publications such as Zentralblatt für

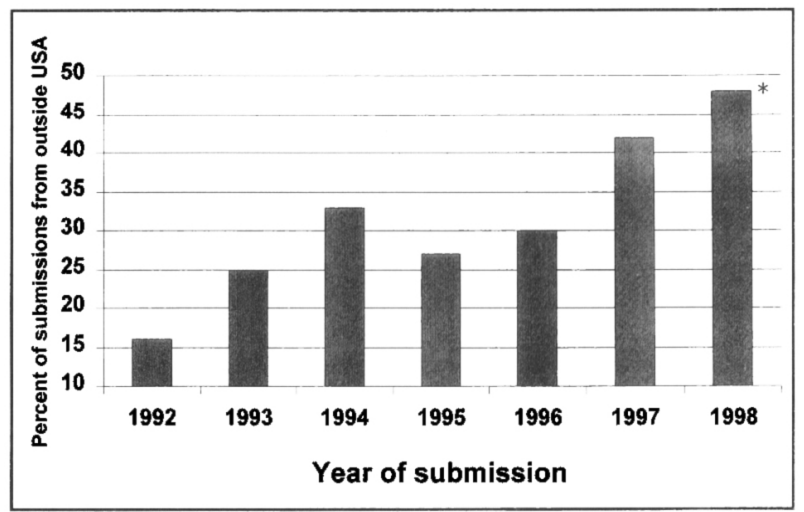

FIGURE 2. Proportion of international contributions to Infection Control and Hospital Epidemiology, 1992 to 1998.

* Submissions as of October 1,1998 . Accepted submissions may have been published in the year of submission or thereafter.

Mikrobiologie und Hygiene, first issued in 1894, Journal of Hygiene (Cambridge) in 1938, and the Journal of Hospital Infection (London) in 1980. The increasing number of nonUS contributions to Infection Control and Hospital Epidemiology in the last 7 years (Figure 2) reflects the growing scientific interest around the globe in problems dealing with NIs, as well as trends towards increasing use of epidemiological tools to control infections. Articles in this issue are from Australia, Belgium, Brazil, China, Israel, The Netherlands, Pakistan, Switzerland, and the United States; one is a fascinating report of an outbreak of nosocomial malaria in a country that has had no malaria for decades-a paradigm for the internationalization of IC.

Much has been learned in Europe from US-based research. US researchers have learned-or may learnfrom experience outside the United States; examples might include antibiotic control, as pioneered in Scandinavian countries; selective digestive decontamination to reduce endogenous infections in high-risk critically ill patients; or more widespread use and promotion of hand antisepsis rather than conventional hand washing to prevent crossinfections, as suggested by Semmelweis in 1847. As we enter an exciting future of fruitful worldwide collaboration for infection control, Infection Control and Hospital Epidemiology will continue to provide an excellent international platform to exchange information, in which the fate of a contribution is determined by quality and not by country of origin.

\section{REFERENCES}

1. LaForce FM. The control of infections in hospitals: 1750 to 1950 . In: Wenzel RP, ed. Prevention and Control of Nosocomial Infections. Baltimore, MD: Williams \& Wilkins; 1993:1-12.

2. Haley RW, Culver DH, White JW, Morgan NW, Emori TG, Munn WP, et al. The efficacy of infection surveillance and control programs in preventing nosocomial infections in US hospitals. Am J Epidemiol 1985;121:182-205.

3. Report of a combined working party of the British Society for Antimicrobial Chemotherapy, the Hospital Infection Society and the Infection Control Nurses Association: revised guidelines for the control of methicillin-resistant Staphylococcus aureus infection in hospitals. I Hosp Infect 1998;39:253-290.

4. Crowe MJ, Cooke EM: Review of case definitions for nosocomial infection-towards a consensus. Presentation by the Nosocomial Infection 
Surveillance Unit (NISU) to the Hospital Infection Liaison Group, subcommittee of the Federation of Infection Societies (FIS). J Hosp Infect 1998;39:3-11.

5. Reybrouck G. The situation in Belgium and The Netherlands. Zentralbl Hyg Umweltmed 1996;199:178-187.

6. Koninklijk Besluit van 24 april 1974 houdende aanvulling van het Koninkliik Besluit van 23 oktober 1964 tot bepaling van de normen die door de ziekenhuizen en hun diensten moeten worden nageleefd. Arrêté Royal du 24 avril 1974 complétant l'arrêté Royal du 23 octobre 1964 portant sur la fixation des normes auxquelles les hôpitaux et leurs services doivent répondre. Belgisch Staatsblad 19 juli 1974.

7. Mertens R, Kegels G, Stroobant A, Reybrouck G, Lamotte JM, Potveliege $\mathrm{C}$, et al. The national prevalence survey of nosocomial infections in Belgium. J Hosp Infect 1984;9:219-229.

8. De Wever A. Fonctionnement du comité d'hygiène hospitalière. Hôpital belge 1980;148:35-48.

9. Koninklijk Besluit van 15 december 1987 houdende uitvoering van de artikels 13 tot en met 17 van de wet op de ziekenhuizen, zoals gecoördineerd door het Koninklijk Besluit van 7 augustus 1987. Arrêté Royal du 15 décembre 1987 portant exécution des articles 13 à 17 inclus de la loi sur les hôpitaux, coordonée par arrêté Royal du 7 août 1987. Belgisch Staatsblad 25 december 1987.

10. Koninklijk Besluit van 7 november 1988 houdende aanvulling van het Koninklijk Besluit van 23 october 1964 tot bepaling van de normen die door de ziekenhuizen en hin diensten moeten worden nageleefd. Arrêté Royal du 7 novembre 1988 complétant l'arrêté Royal du 23 octobre 1964 portant sur la fixation des normes auxquelles les hôpitaux et leurs services doivent répondre. Belgisch Staatsblad 24 november 1988.

11. Ojajärvi J. The situation of hospital hygiene in Scandinavia. Zentralbl Hyg Umweltmed 1996;199:172-177.

12. Nyström B. Infection control policies and guidelines-Scandinavian experience. J Hosp Infect 1991;18:106-109.

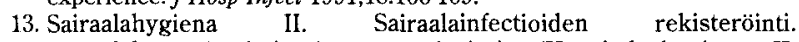
Sairaalahygieniatoimintojen organisointi. (Hospital hygiene II. Surveillance of hospital infections. Organization of hospital infection control activities). Suositus 16.4.1981. Sairaalatitto, jukaisu 2/1981.

14. Brïcker G. Actual state of hospital hygiene in France. Zentralbl Hyg Umweltmed 1996;199:156-167.

15. Richtlinien des Robert-Koch-Instituts für Krankenhaushygiene und Infektionsprävention. Jena, Germany: Gustav Fischer Verlag; 1991.

16. Zastrow KD, Schoneberg.I. Results on the status of the organizational structures in hospital hygiene in Germany, I: overall evaluation with special reference to acute hospitals. Gesundheitswesen 1993;55:55-59.

17. Gastmeier P, Kampf G, Wischnewski N, Hauer T, Schulgen G, Schumacher M, et al. Prevalence of nosocomial infections in representative German hospitals. J Hosp Infect 1998;38:37-49.

18. Gastmeier P, Sohr D, Koch J, Geffers C, Nassauer A, Daschner F, et al. Creation of a reference data system for surveillance of nosocomial infections. Klinikarzt 1998;27:204-209.

19. Emmerson AM. Hospital hygiene in Great Britain. Zentralbl Hyg Umweltmed 1996;199:168-171.

20. Teare EL, Peacock A. The development of an infection control linknurse programme in a district general hospital. $J$ Hosp Infect $1996 ; 34: 267-278$.

21. Ayliffe GA. Cross-sectional surveys of infection. In: Brachman PS, Eichkhoff TC, eds. Proceedings of the International Conference on Nosocomial Infections. Chicago, IL: American Hospital Association; 1971:282-284.

22. Meers PD, Ayliffe GAJ, Emmerson AM, Leigh DA, Mayon-White RT, Mackintosh CA, et al. Report on the National Survey of Infection in Hospitals. J Hosp Infect 1980;2(suppl):1-51.
23. Emmerson AM, Enstone JE, Griffin M, Kelsey MC, Smyth ETM. The second national prevalence survey of infections in hospitals-overview of the results. J Hosp Infect 1996;32:157-190.

24. Infection Control Standards Working Party, Public Health Laboratory Service. Standards in Infection Control in Hospitals. London, England: PHLS; 1993.

25. Infection Control Standards Working Party, Public Health Laboratory Service. Hospital Infection Control; Guidance on the Control of Infection in Hospitals. London, England: PHLS; 1995.

26. Preventie en bestrijding van ziekenhuiseninfecties. 's-Gravenhage, Nederland: Gezonheidsraad; 1990.

27. Paardekooper JL, Veerman-Brenzikofer M, Wille JC, Hoog-Rueb W. VHIG-Enquête 1991. Tijdschr Hyg Infectieprev 1992;11:86-89.

28. Richtlijnen ter preventie en bestrijding van zikenhuisinfecties, 4 de druck. 's-Gravenhage, Nederland: Staatsuitgeverij; 1968.

29. Richtlijnen voor een reglement van de infectiecommissie in een ziekenhuis. Leidschendam, Nederland: Geneesekundige Hoofdispectie van de Volksgezondheid; 1977.

30. Besluit eisen voor erkenning ziekenhuizen. 's-Gravenhage, Nederland: Nederlandse Staatscourtant; November 29, 1984.

31. Backe B, Sander J, Lingaas E. Infection control in Norwegian somatic hospitals, 1990. Tidsskr Nor Laegeforen 1992;112:237-244.

32. Plitt-Gomez C, Molina-Quilis R, Ruiz-Bremon A, de Pedro-Cuesta J. Nursing in nosocomial infection control in Spain. $J$ Adv Nurs $1995 ; 21: 440-446$.

33. Vaque J, Rossello J, Trilla A, Monge V, Garcia-Caballero J, Arribas JL, et al. Nosocomial infections in Spain: results of five nationwide serial prevalence surveys (EPINE Project, 1990 to 1994). Nosocomial Infections Prevalence Study in Spain. Infect Control Hosp Epidemiol 1996;17:293297.

34. Trilla A, Vaque J, Rasello J, Salles M, Marco F, Prat A, et al. Prevention and control of nosocomial infections in Spain: current problems and future trends. Infect Control Hosp Epidemiol 1996;17:617-622.

35. Subdireccion General de Prestaciones y Evaluacion de Tecnologias Sanitarias (Ministerio de Sanidad y Consumo): Informe dubre Infeccion Hospitalaria. Med Clin (Barc) 1994;102:20-24.

36. Pittet D, Francioli P, von Overbeck J, Raeber PA, Ruef C, Widmer AF. Infection control in Switzerland. Infect Control Hosp Epidemiol 1995; 16:49-56.

37. Pittet D, Harbarth S, Ruef C, Francioli P, Sudre PH, Pétignat C, et al. Prevalence and risk factors for nosocomial infections in four university hospitals in Switzerland. Infect Control Hosp Epidemiol 1999;20:37-42.

38. Spencer RC. Prevalence studies in nosocomial infections [editorial]. Eur $J$ Clin Microbiol Infect Dis 1992;11:95-98.

39. French GL, Cheng AF, Wong SL, Donnan S. Repeated prevalence surveys for monitoring effectiveness of hospital infection control. Lancet 1989;2:1021-1023.

40. Vincent JL, Bihari DJ, Suter PM, Bruning HA, White G, NicolasChanioin $\mathrm{MH}$, et al. The prevalence of nosocomial infection in intensive care units in Europe. Results of the European Prevalence of Infection in Intensive Care (EPIC) Study. JAMA 1995;274:639-644.

41. Daschner FD, Frey P, Wolff G, Baumann PC, Suter P. Nosocomial infections in intensive care wards: a multicenter prospective study. Intensive Care Med 1982;8:5-9.

42. Huskins WC, O'Rourke EJ, Rhinehart E, Goldman DA. Infection control in countries with limited resources. In: Mayhall CG, ed. Hospital Epidemiology and Infection Control. Baltimore, MD: Williams \& Wilkins; 1996:1176-1200.

43. European Community COMAC: EURO.NIS Nosocomial Infection Surveillance, Phase 2B. ISSN 0017-9124. Health Services Research; 1991. 